\title{
Enhanced Heat Transfer on Thermo Active Cooling Wall
}

\author{
Samo Venko1,* - Boris Vidrih ${ }^{2}$ - Erik Pavlovič 1 - Sašo Medved ${ }^{2}$ \\ ${ }^{1}$ Hidria IMP Klima d.o.o., Slovenia \\ 2 University of Ljubljana, Faculty of Mechanical Engineering, Slovenia
}

In the article a study of the cooling potential of thermo activated wall in an office building with enhanced convective heat transfer is presented. Heat transfer on a vertical cooled wall is enhanced by a longitude jet of supply fresh air from diffuser mounted parallel on the top of the wall. Such a system is compared to an adequate system with natural convection heat transfer from the cooled surface.

Empirical models in the form of multicriterial polynoms for local and average convective heat transfer coefficients determination were developed for natural and enhanced convection using CFD techniques. Empirical models were used in the TRNSYS simulation tool for analyzing cooling potential increasing in the case of enhanced heat transfer on a cooled wall surface in a typical office. Results show a significant increase of the cooling load, a decrease of energy consumption for cooling of the office and better adaptive thermal comfort if heat transfer is enhanced with longitude jet of fresh supply air.

Keywords: free cooling, thermo active building systems, enhanced convection heat transfer, thermal comfort, numeric heat transfer

\section{INTRODUCTION}

Regarding expected climate changes, microclimate conditions in urban areas, the trend of population ageing, the energy consumption for the cooling of the buildings will be very important for ensuring the indoor thermal comfort as well as for approaching the near zero energy buildings in the near future [1] and [2]. In addition to architecture measures, free cooling offers a significant potential for the decrease of energy demand in the buildings. Such systems can be constructed in the form of a thermo active building system (TABS) and has recently become widely used for buildings cooling because of their undisputed advantages. Advantages are most recognized in office buildings with high cooling demands. Kalz et al. [3] describe TABS as a building construction elements thermally activated by water or air driven systems that operate with small temperature differences between indoor air and heating ventilating and air conditioning HVAC system supply temperatures. This enables the use of low exergy heating and cooling sources like ground water, borehole heat exchangers, earth-to-air heat exchangers, cooling towers and solar collectors. Optimal designed TABS in low-energy demand office buildings can provide a thermal comfort which meets $10 \%$ PPD even without mechanical cooling. Kalz et al. report a decrease of energy consumption by $50 \%$ in low energy buildings designed with TABS. Lehmann et al. [4] showed for office building cooled by thermally active concrete slab with a thickness of $300 \mathrm{~mm}$ that maximal cooling load up to $53 \mathrm{~W} / \mathrm{m}^{2}$ can be achieved if maximal permissible daily indoor air temperature amplitude of $5 \mathrm{~K}$ can be tolerated. Koschenz and Dorer [5] studied a relation between heat loads and indoor air temperature in the room with thermal activated concrete slab. Košir et al. found that the usage of cooling wall panels coupled with optimal surface temperatures results in considerable energy reduction and better indoor comfort [6]. Henze et al. [7] made a study about energy consumption and thermal comfort in buildings with all air systems and air systems combined with TABS for cooling of an office building. They point out that the operation of TABS and air conditioning must be synchronized to ensure energy efficient cooling. If so, the TABS heat sink was fairly constant at $30 \mathrm{~W} / \mathrm{m}^{2}$ during cooling season and $20 \%$ less primary energy is needed compared to all the air system. Cooling with TABS also contributes to better indoor thermal comfort. During the summer all the air system was associated with a fairly constant PMV value of 0.75 , comparing 0.56 for the combined system. This results in $12 \%$ instead of $17 \%$ PPD. Dovjak et al. found [8] that energy usage for cooling is by 41 to $62 \%$ lower for high surface temperature cooling ceiling systems comparing conventional cooling systems at similar thermal comfort.

In all of the presented research, natural convection heat transfer was assumed. Since contemporary nonresidential buildings are all mechanically ventilated, forced air movement caused by ventilation system can be used for enhanced heat transfer on TABS surfaces resulting in mixed convection heat transfer. Kobus and Wedekind [9] defined mixed convection as the mode of convective heat transfer which is neither dominant by forced convection nor natural convection, but it is a combination of those two regimes. Yang and Panel [10] studied mixed convection heat transfer on vertical wall caused by downwards and upwards air jets. Upward jet flows were either aiding flows, if $\vartheta_{\mathrm{w}}>\vartheta_{\mathrm{SA}}$, either opposing flows when $\vartheta_{\mathrm{w}}<\vartheta_{\mathrm{SA}}$. Angirasa [11] 
found that upwards plan air jet over a hotter wall is identical to the downward air jet over the colder wall. Mokni et al. [12] studied assisted upward plane air jets with laminar and parabolic uniform velocity discharge profile. They found that discharge velocity profile highly affects convection only in jet zone. Neiswanger et al. [13] set a model for an average heat transfer coefficient for mixed convection as a general relation between natural and forced convection. This model enables determination of forced convection increase of average heat transfer coefficient. Awbi and Hatton [14] carried out experiments with a jet over an enclosure heated surfaces representing small room with interior dimensions $2.78 \times 2.78 \times 2.3$ $\mathrm{m}$. Neiswanger model for mixed convection and developed empirical models for an average heat transfer coefficients for forced convection supplement of mixed convection was used. Models are based on measured average heat transfer coefficients for mixed convection and empirical models for an average heat transfer coefficient of natural convection from their previous research [15]. Goldstein and Novoselac [16] studied mixed convection on vertical surfaces generated by ceiling slot diffusers. Their study shows that temperature difference between surface and supply air does not affect average convective heat transfer rate from cooled vertical wall. An average convective heat transfer is also independent of diffuser distance from the wall if distance is less than $23 \mathrm{~cm}$.

The presented research results in enhanced convective heat transfer caused by plane wall air jet have shown that heat transfer from TABS surface could be significantly enlarged. Authors mainly analyze average convective heat transfer coefficient at specific boundary conditions, but no research on enhanced local heat transfer coefficient on thermal activated cooling wall by longitude jet of fresh supply air was found. In the presented study empirical expressions of local and average convective heat transfer coefficient on thermal activated cooling wall (TACW) in the case of natural and enhanced convection heat transfer were developed. Those expressions were afterwards used for modeling of energy demand and indoor thermal comfort in a typical office room cooled with TACW and compared to the free cooling systems without enhanced heat transfer.

\section{MODELING OF LOCAL AND AVERAGE CONVECTIVE HEAT TRANSFER COEFFICIENT ON TACW IN CASE OF NATURAL AND ENHANCED CONVECTION}

\subsection{Natural Convection on TACW}

Computational fluid dynamic (CFD) tools is nowadays widely used owing to their user friendliness and wide range of validation. In the presented research Ansys Fluent 13.0 code was used for CFD simulation of temperature, pressure and velocity filed in selected office. Two-dimensional room space with length of $5 \mathrm{~m}$ and height of $3 \mathrm{~m}$, presented in Fig. 1 . was assumed to speed up the numerical solutions. Natural convection heat transfer was analyzed over TACW having constant surface temperature boundary condition. Surface temperature was maintained at $\vartheta_{\text {TACW }}=20{ }^{\circ} \mathrm{C}$. The opposite wall was supposed to be heat source emit uniformly convective heat flux between 2.5 and $63 \mathrm{~W} / \mathrm{m}^{2}$. Convection was only heat transfer mechanize taken into account on all surfaces.

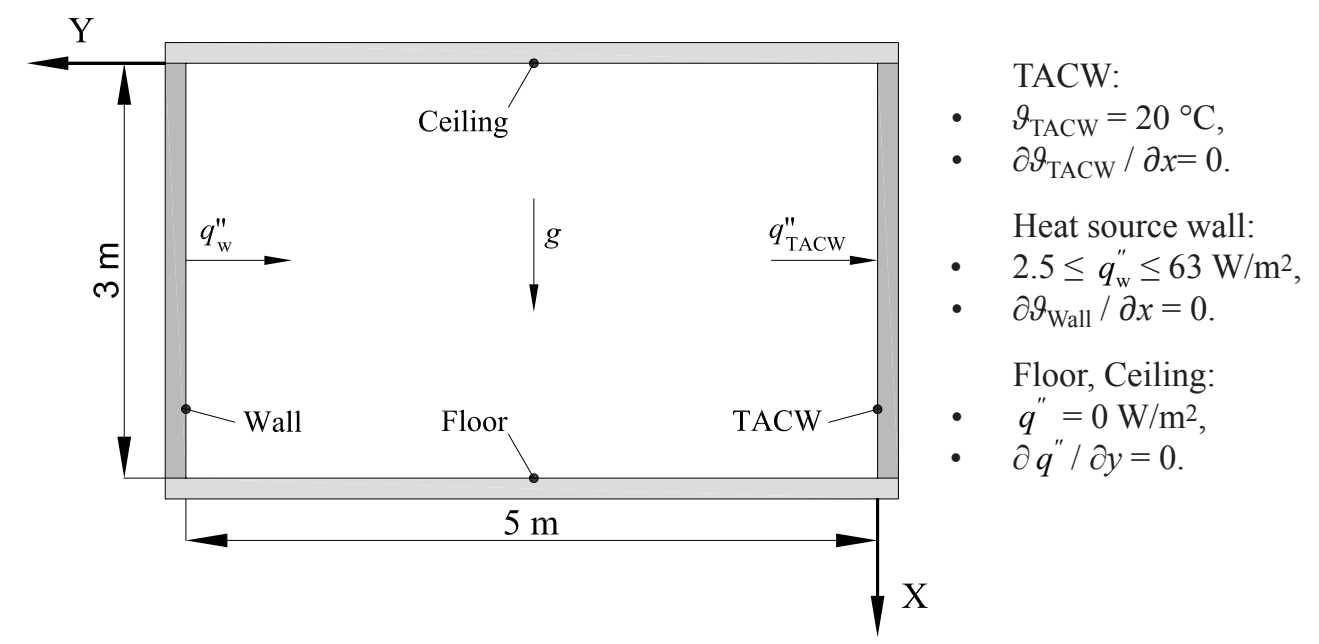

Fig. 1. Geometry of 2D office room model and boundary conditions used in numerical simulations for natural convection heat transfer from TACW 
High density orthogonally meshes were used and we were focused on very fine mesh at TACW surface. The thickness of the first cell at the wall boundary was $0.14 \mathrm{~mm}$, each neighbor layers was increased by the factor 1.08 comparing the previous one. The domain was divided into 114,660 elements with maximal mesh skewness 0.3 and minimal orthogonal of 0.97 which allow high quality of numerical solution.

The mesh was tested with mesh independent criteria because the worst strategy would be to avoid this subject and to provide numerical simulations on a single computational grid [17]. Following settings of Ansys Fluent solver were used: double precision, k-omega viscosity model: SST, disabled radiation, incompressible ideal gas, coupled pressure-velocity field, last squares cell based gradient, PRESTO pressure model, second order upwind momentum, second order upwind turbulent kinetic energy, specific dissipation rate and energy model, explicit relaxation factors for momentum (0.3) and pressure (0.5), underrelaxation factors for density (0.6), body forces (1), turbulent kinetic energy (0.5), specific dissipation rate $(0.5)$, turbulent viscosity (0.7) and energy (1), residual for continuity (0.0026), $x$-velocity $(0.0001), y$-velocity $(0.0001)$ and energy $\left(1 \times 10^{-7}\right)$. Steady state conditions were assumed.

From local convective surface heat flux $q_{\mathrm{TACW}}^{\prime \prime}(x)$ the local convective heat transfer coefficient was determined:

$$
h_{\mathrm{c}}(x)=q_{\mathrm{TACW}}^{\prime \prime}(x) / \Delta \vartheta .
$$

Temperature difference $\Delta \vartheta$ presents temperature difference between an average room air temperature and TACW surface temperature:

$$
\Delta \vartheta=\vartheta_{\mathrm{i}}-\vartheta_{\mathrm{TACW}}
$$

Average convective heat transfer coefficient $h_{\mathrm{c}, \mathrm{avg}}$ can be calculated from the known average surface heat flux $q_{\mathrm{c} \text {,avg }}^{\prime \prime}$ Eq. (1) and we approximated it with Eq. (3) meanwhile the local convective heat transfer coefficient on TACW is approximated with Eq. (4):

$$
\begin{gathered}
h_{\mathrm{c}, \mathrm{avg}}=0.609 \cdot \ln (\Delta \vartheta)+1.182, \\
h_{\mathrm{c}}(x)=A+B \mathrm{e}^{-C \cdot x},
\end{gathered}
$$

where functions $A, B$ and $C$ are equal to:

$$
\begin{gathered}
A=0.52503 \cdot \ln (\Delta \vartheta)+1.3515, \quad 0 \mathrm{~m} \leq x \leq 3 \mathrm{~m}, \\
B=0.91764 \cdot \ln (\Delta \vartheta)+1.2844, \quad 0 \mathrm{~m} \leq x \leq 1.5 \mathrm{~m}, \\
B=1.0332 \cdot 10^{-11} \cdot(\Delta \vartheta)^{4}-5.0926 \cdot 10^{-10} \cdot(\Delta \vartheta)^{3}+ \\
+3.544 \cdot 10^{-9} \cdot(\Delta \vartheta)^{2}+1.4908 \cdot 10^{-7} \cdot \Delta \vartheta-1.987 \cdot 10^{-6}, \\
1.5 \mathrm{~m} \leq x \leq 3 \mathrm{~m},
\end{gathered}
$$

$$
\begin{gathered}
C=-1.374 \cdot 10^{-4} \cdot(\Delta \vartheta)^{5}+9.1717 \cdot 10^{-3} \cdot(\Delta \vartheta)^{4}- \\
-0.21987 \cdot(\Delta \vartheta)^{3}+2.2566 \cdot(\Delta \vartheta)^{2}- \\
-9.1091 \cdot \Delta \vartheta+26.2996 \\
0 \mathrm{~m} \leq x \leq 1.5 \mathrm{~m} \\
C=-3.19 \cdot 10^{-5} \cdot(\Delta \vartheta)^{4}+8.995 \cdot 10^{-4} \cdot(\Delta \vartheta)^{3}- \\
-8.5331 \cdot 10^{-3} \cdot(\Delta \vartheta)^{2}-0.03632 \cdot \Delta \vartheta-4.456 \\
1.5 \mathrm{~m} \leq x \leq 3 \mathrm{~m} .
\end{gathered}
$$

The Eqs. (3) and (4) are valid for $2 \leq \Delta \vartheta \leq 20^{\circ} \mathrm{C}$, for the closed room with dimensions presented in Fig. 1 and room without any forced air movement. In Fig. 2 approximated local convective heat transfer coefficient $h_{\mathrm{TACW}}$ over TACW for temperature differences $2.5 \leq \Delta \vartheta \leq 20{ }^{\circ} \mathrm{C}$ are plotted. Three sub regions regarding to heat transfer coefficient can be noticed: ceiling region at distance $0<x \leq 0.5 \mathrm{~m}$, mid region $0.5<x \leq 2.5 \mathrm{~m}$ and the floor region at $2.5<x \leq 3 \mathrm{~m}$. Heat transfer coefficient is the largest and most dependent on temperature difference $\Delta \vartheta$ at the ceiling region and significantly decreases with an increase of the room high. In mid region heat transfer coefficient is fairly constant and almost independent of the distance from the ceiling. At floor region convective heat transfer coefficient sharply decreases and reaches minimal value of $0.28 \mathrm{~W} /\left(\mathrm{m}^{2} \mathrm{~K}\right)$ for all analyzed temperature differences.

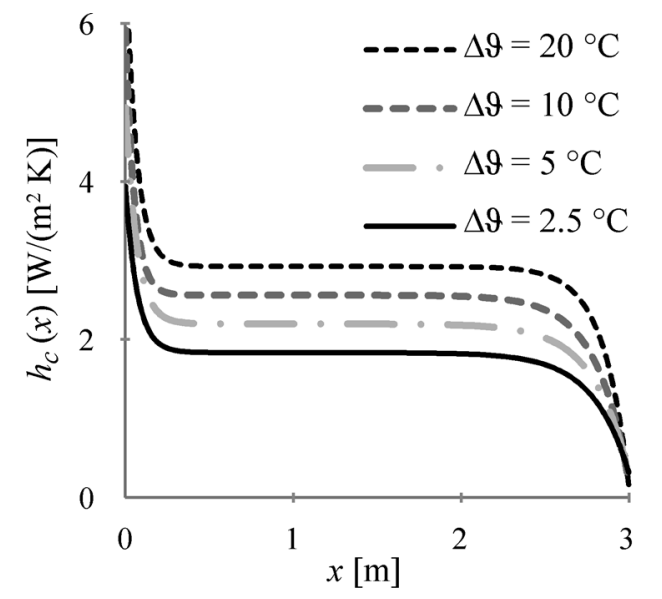

Fig. 2. Approximated local heat transfer coefficient for natural convection on TACW for temperature difference $2.5 \leq \Delta \vartheta \leq 20^{\circ} \mathrm{C}$

A comparison between numerical results and approximated values due Eqs. (3) and (4) for selected cases is presented in Fig. 3 and shows good agreement between approximated and numerical results.

To the best knowledge of the authors, no model of local temperature dependent convective heat transfer coefficient on TACW has been reported; only average convective heat transfer coefficient model from our 

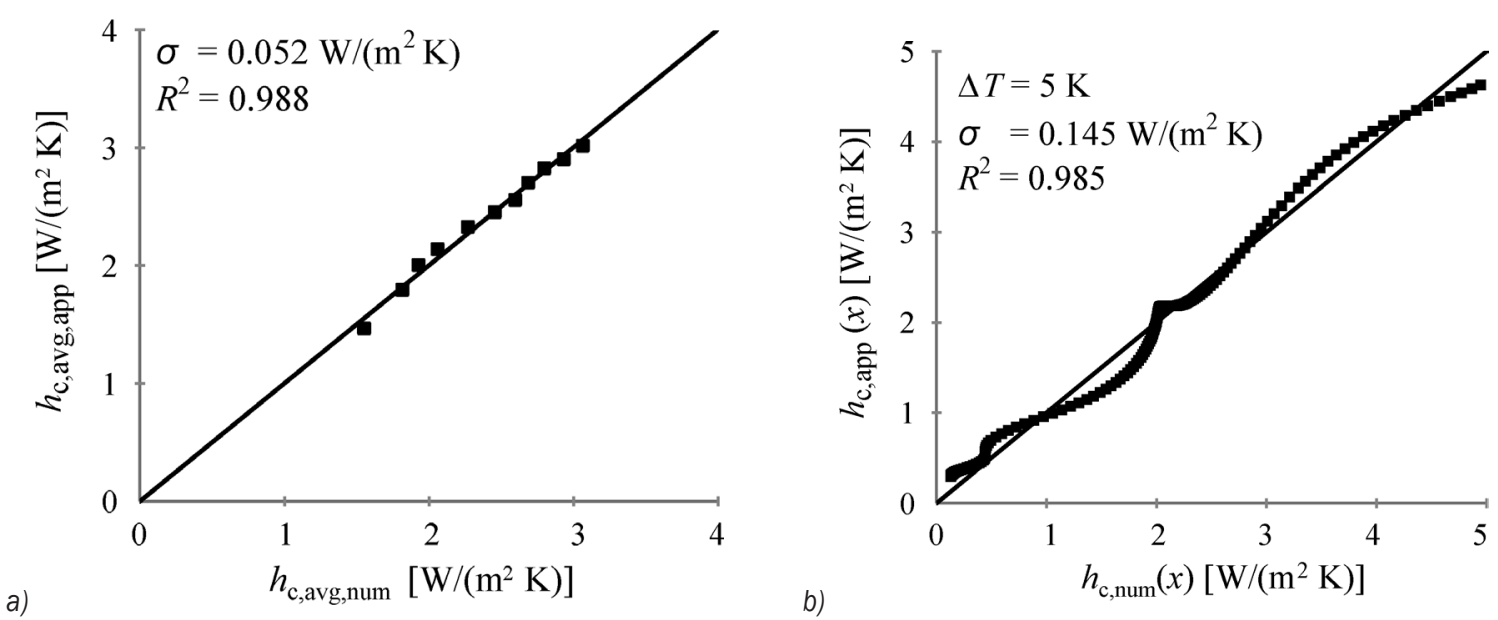

Fig. 3. Comparison between a) average $h_{c, \text { avg }}$ and b) local $h_{c}(x)$ convective heat transfer coefficient determinate by approximation function and numerical results

study can be verified. ASHRAE [18] suggest the following approximation:

$$
h_{\mathrm{c}, \mathrm{avg}}=1.31(\Delta \vartheta)^{0.33},
$$

meanwhile Khalifa and Marshall [15] proposed a model, which is valid for temperature differences $\Delta \vartheta$ lower than $5 \mathrm{~K}$ only:

$$
h_{\mathrm{c}, \mathrm{avg}}=1.983(\Delta \vartheta)^{0.25} \text {. }
$$

Fig. 4 shows an average heat transfer coefficient on TACW calculated for temperature differenced $\Delta \vartheta$ in range of 2 to $10{ }^{\circ} \mathrm{C}$ using different models. It can be noticed that Khalifa and Marshall [19] model differ significantly regarding to present the study and the ASHRAE model and that results of the presented study are similar to the ASHRAE model up to $\Delta \vartheta=5{ }^{\circ} \mathrm{C}$, with only small differences in case of larger temperature differences $\Delta \vartheta$. Therefore, it can be concluded that boundary conditions, meshing and solver settings in the presented numerical modeling is adequate.

\subsection{Enhanced Convection on TACW}

An analysis of enhanced convective heat transfer by downwards plan air jet of fresh supply air was done with the code Ansys Fluent 13.0 using the same mesh, solver setting and boundary conditions as they were used in the case of natural convection. Only differences were applied for residual criteria: continuity (0.0001), $x$-velocity (0.0001), $y$-velocity $(0.0001)$, Energy $\left(10^{\cdot} \cdot 10^{-7}\right)$. As in the previous case, steady state conditions were assumed.

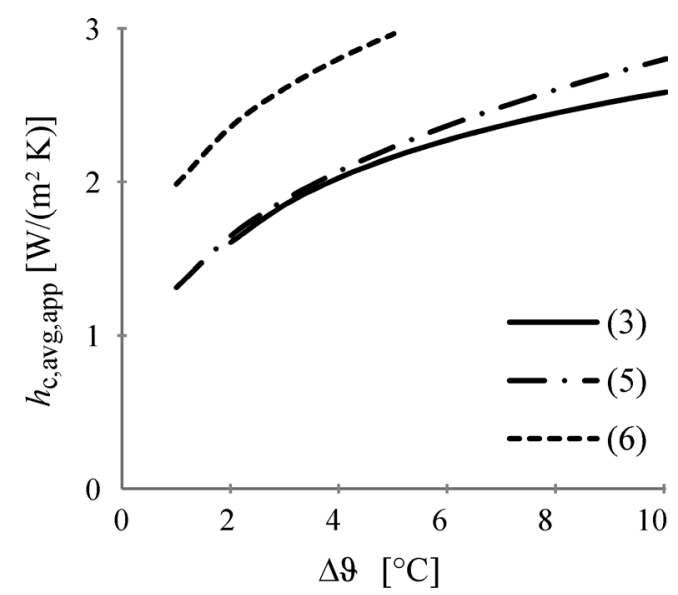

Fig. 4. Average convection heat transfer $h_{c, a v g}$ coefficient for natural convection on TACW calculated using different models (3), (5) and (6)

The fresh air is supplied through the ceiling slot having width $w$ equal to $10 \mathrm{~mm}$ and installed at the top of the TACW (at $x=0$ ) as it is shown in Fig. 5. Velocities $v_{\mathrm{SA}}$ of supply air, having constant temperature $\vartheta_{\mathrm{SA}}=27^{\circ} \mathrm{C}$, were selected in the range between 1 and $4 \mathrm{~m} / \mathrm{s}$. Surface temperature of TACW was varied in range of $17 \leq \vartheta_{\mathrm{TACW}} \leq 26^{\circ} \mathrm{C}$ and the difference between wall temperature and supply air temperature in the range of $-10 \leq \Delta \vartheta \leq-1{ }^{\circ} \mathrm{C}$. Minimum supply air velocity $v_{\mathrm{SA}}=1 \mathrm{~m} / \mathrm{s}$ was selected according to a minimal amount of fresh air, maximal velocity $v_{\mathrm{SA}}=4 \mathrm{~m} / \mathrm{s}$ according to the good practice where higher velocity causes discomfort in ventilated rooms. Reject air was extracted through the opening in the ceiling with the same flow rate. The position of the outlet opening was selected by numerical simulations 


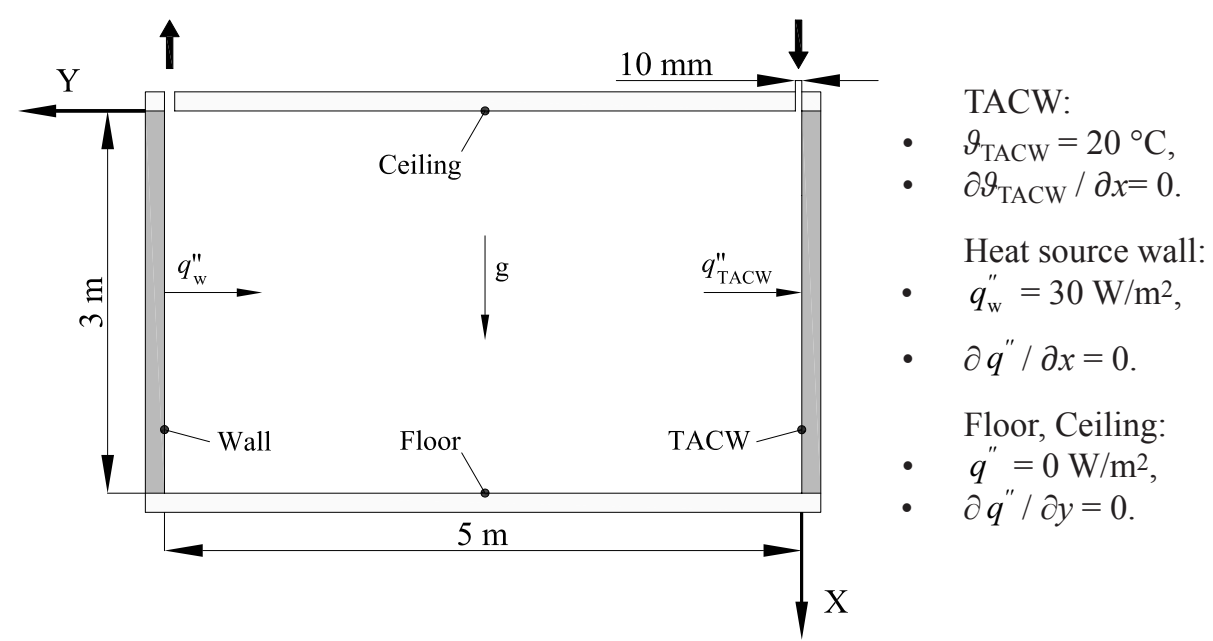

Fig. 5. Geometry of $2 D$ office room model and boundary conditions used in numerical simulations for modeling of enhanced convection heat transfer over TACW

in the way not to influence heat transfer on TACW. Using reference temperature difference proposed by Spitler et al. [20] and [21]:

$$
\Delta \vartheta=\vartheta_{\mathrm{SA}}-\vartheta_{\mathrm{TACW}}
$$

and average surface heat flux $q_{\mathrm{c}, \text { avg }}^{\prime \prime}$ Eq. (1) over TACW, enhanced average convective heat transfer coefficient $h_{\mathrm{c} \text {,avg }}$ was approximated with Eq. (8) and local convective heat transfer coefficient over TACW with Eq. (9).

From numerical results it was found that reference temperature difference has no influence on the convective heat transfer on TACW and therefore convective heat transfer coefficients can be approximated as a function of $v_{\mathrm{SA}}$ only. The same conclusion was reported by Goldstein and Novoselac [16].

$$
\begin{gathered}
h_{\mathrm{c}, \mathrm{avg}}=2.1547 \cdot v_{\mathrm{SA}}+0.9942, \\
h_{\mathrm{c}}(x)=A+B \mathrm{e}^{(C \cdot x+\mathrm{D}),}
\end{gathered}
$$

where functions $A, B, C$ and $D$ are equal to:

$$
\begin{gathered}
A=0.2333 \cdot v_{\mathrm{SA}}+0.3667, \\
B=1.3429 \cdot \ln \left(v_{\mathrm{SA}}\right)+1.6261, \\
C=-0.082966 \cdot v_{\mathrm{SA}}-0.37768, \\
D=-6.5643 \cdot 10-3 \cdot v_{\mathrm{SA}}+0.13796 \cdot v_{\mathrm{SA}}{ }^{4}- \\
-1.0324 \cdot v_{\mathrm{SA}}{ }^{3}+3.53468 \cdot v_{\mathrm{SA}}{ }^{2}-5.2852 \cdot v_{\mathrm{SA}}+3.9115 .
\end{gathered}
$$

Approximation functions (8) and (9) are valid for slot width $w=0.01 \mathrm{~m}, 1 \leq v_{\mathrm{SA}} \leq 4 \mathrm{~m} / \mathrm{s}$, $2 \leq \Delta \vartheta \leq 20^{\circ} \mathrm{C}$ and for a closed room. Approximated enhanced local convection heat transfer coefficient is shown in Fig. 6. It can be noticed that heat transfer coefficients decrease regarding the distance along the TACW and increase with supply air velocity.The approximated values of average and local convective heat transfer coefficients were compared to numerical solutions in Fig. 7. All numerical simulations are included for $h_{\mathrm{c} \text {,avg }}$ and the selected case is presented for $h_{\mathrm{c}}(x)$.

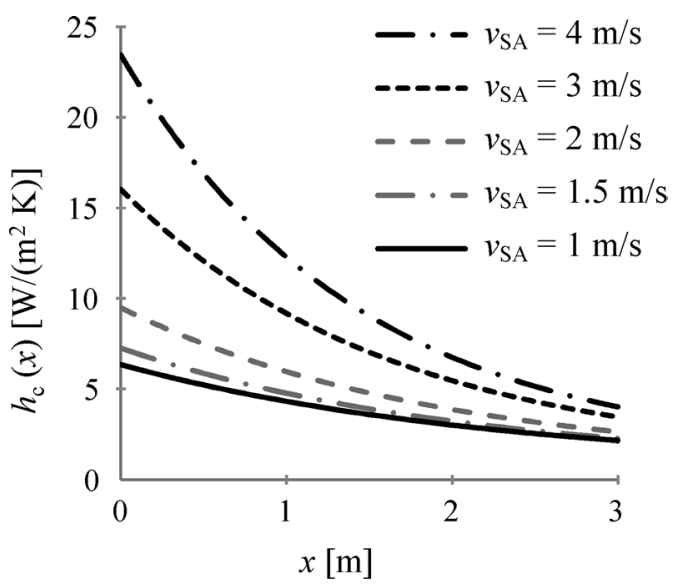

Fig. 6. Local heat transfer coefficients for mixed convection on cooled wall for $1 \leq v_{\mathrm{SA}} \leq 4 \mathrm{~m} / \mathrm{s}$ calculated due to (9)

\section{THERMAL RESPONSE OF OFFICE COOLED WITH TACW}

Cooling of the typical office with natural and enhanced convection on TACW was studied using the TRNSYS simulation tool [22] and climate data from the Test Reference Year (TRY) for Ljubljana, Slovenia [23]. The office with dimensions of $5 \times 6 \times 3 \mathrm{~m}$ 

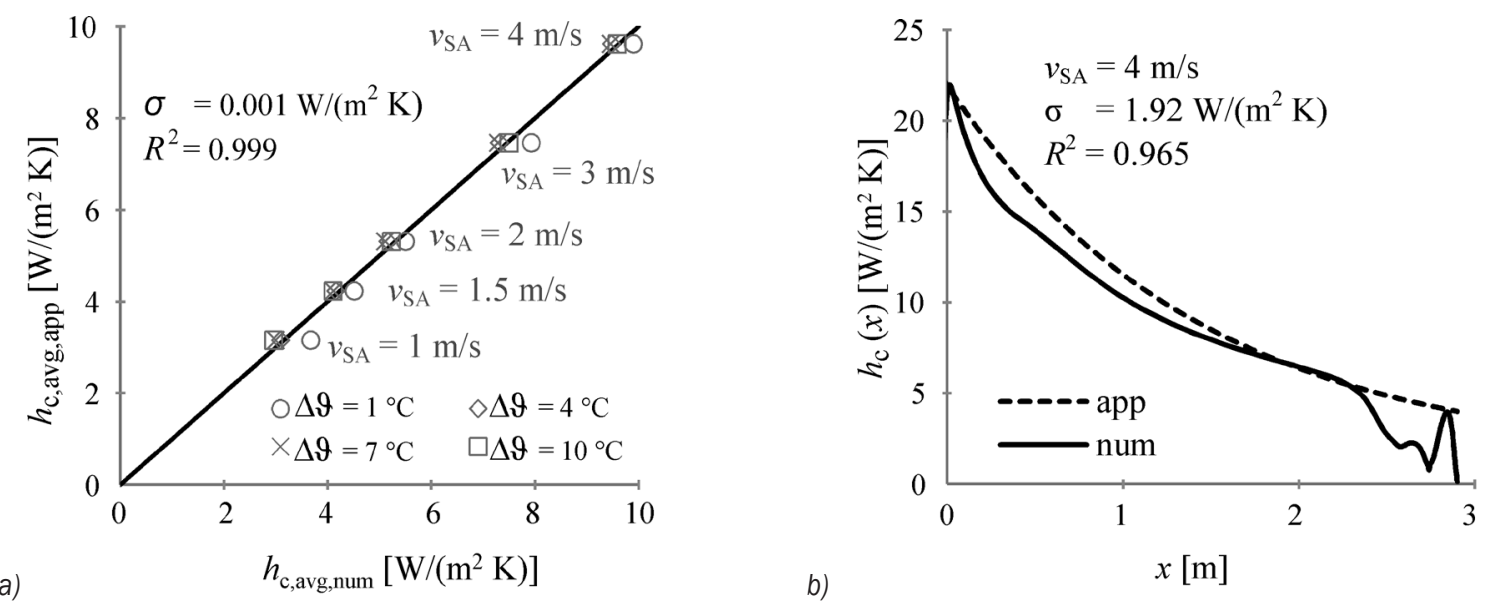

Fig. 7. Comparison between approximated and numerical determinated values for a) average $h_{c, \text { avg }}$ and b) local $h_{c}(x)$

shown in Fig. 8 has one external wall, meanwhile all other walls, the floor and the ceiling were treated as externally adiabatic walls allowing only internal side heat accumulation. The external wall, with heat transfer coefficient $U=0.2 \mathrm{~W} /\left(\mathrm{m}^{2} \mathrm{~K}\right)$, has a window with $U_{\text {win }}=0.7 \mathrm{~W} /\left(\mathrm{m}^{2} \mathrm{~K}\right)$ in half size of the wall. External window shading is activated when solar radiation on horizontal plane exceeds $300 \mathrm{~W} / \mathrm{m}^{2}$. Surface temperature of TACW was maintained at constant temperature $\vartheta_{\mathrm{TACW}}=17{ }^{\circ} \mathrm{C}$. Such surface temperature could, for example, be achieved with mine water at source temperature level $\vartheta=12.8{ }^{\circ} \mathrm{C}$ [26]. The office is mechanically ventilated through the ceiling slot opening positioned at the top of the TACW. The slot is $0.01 \mathrm{~m}$ wide with length equal to TACW's length $3 \mathrm{~m}$ (Fig. 8a) or (Fig. 8b). In all the cases fresh outdoor air flow rate was maintained at 216 $\mathrm{m}^{3} / \mathrm{h}$ in occupied hours (7 AM to $18 \mathrm{PM}$, Monday to Friday) to provide minimal hygienic requirements of 2 $1 /\left(\mathrm{s} \cdot \mathrm{m}^{2}\right.$ floor $)$ for the offices - Classification A according to CR 1752: 1998 [24]. During the unoccupied hours the air exchange rate was reduced to $0.2 \mathrm{l} / \mathrm{h}$ [25]. Supply air passed the heat recovery unit with an effectiveness of $\epsilon=0.75$ when $\vartheta_{\mathrm{e}}>\vartheta_{\mathrm{i}}$. The outlet ceiling slot was positioned at the top of opposite wall. It was found from CFD simulations that outlet ceiling slot does not influence convective heat transfer on TACW if it is more than one half of room length away from TACW.Three levels of internal heat gains were assumed [27]: light level $30 \mathrm{~W} / \mathrm{m}^{2}$, medium level 45 $\mathrm{W} / \mathrm{m}^{2}$ and high level $60 \mathrm{~W} / \mathrm{m}^{2}$. Natural convection and enhance convection over TACW were calculated by using empirical models Eqs. (4) and (9) for local convection heat transfer coefficient developed with CFD. Hour-by-hour thermal response calculation of office room was used for determining the efficiency of free cooling based on the acceptance of indoor environment conditions in none mechanical cooled space.
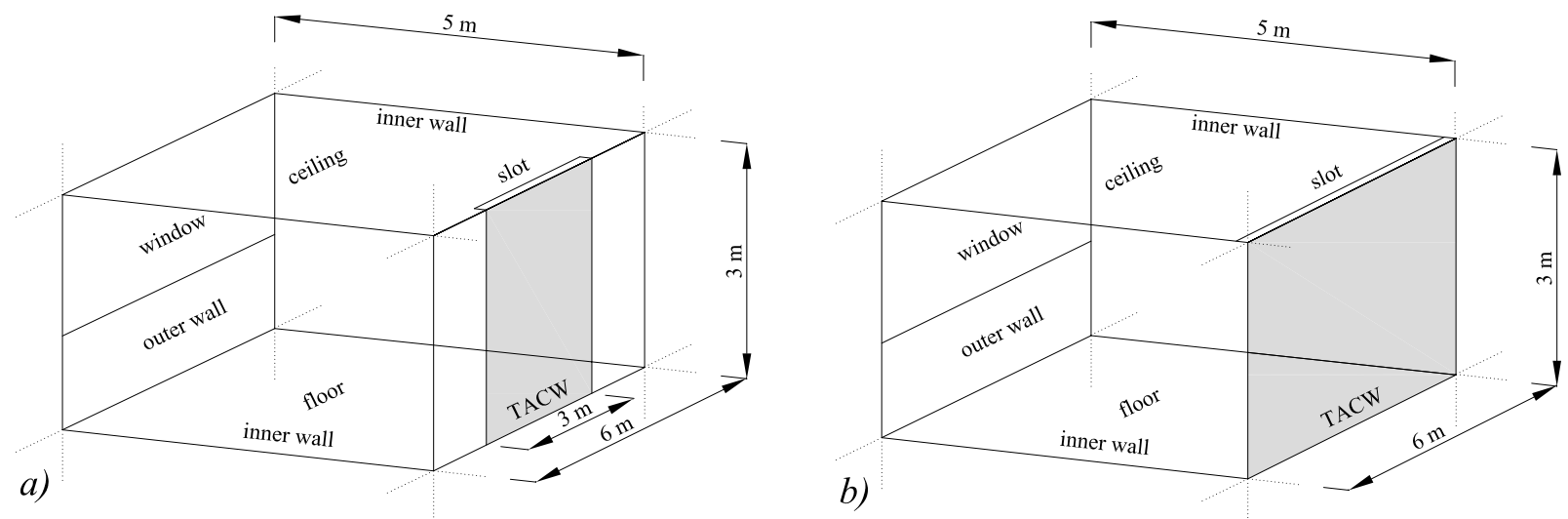

Fig. 8. Analyzed office room with designation of surfaces: a) $L_{\text {TACW }}=3 \mathrm{~m}$, b) $L_{\mathrm{TACW}}=6 \mathrm{~m}$ 


\subsection{Operating Scenarios}

Eight scenarios which were analyzed differ regarding ventilation strategies and the type of convection over TACW. For the first scenario the office without free cooling and mechanical ventilation with outdoor air was assumed. The second scenario was similar, but with additional night cooling with outdoor air with two air changes per hour $\left(A C H=2 \mathrm{~h}^{-1}\right)$ during the unoccupied hours. This scenario was extended in the scenarios $\mathrm{A}_{3}, \mathrm{~A}_{6}, \mathrm{~B}_{3}, \mathrm{~B}_{6}, \mathrm{C}_{3}$ and $\mathrm{D}_{3}$ with additional free cooling of the office using TACW. In scenarios $\mathrm{B}_{3}, \mathrm{C}_{3}, \mathrm{D}_{3}$ the length of TACW was $3 \mathrm{~m}$ and in scenarios $\mathrm{A}_{6}$ and $\mathrm{B}_{6}$ the length of TACW was $6 \mathrm{~m}$. In the scenarios $A_{3}$ and $A_{6}$ natural convection on TACW was presumed, in all other scenarios convection on TACW was enhanced with supply air jet flow. In some scenarios $\left(\mathrm{B}_{6}, \mathrm{C}_{3}, \mathrm{D}_{3}\right)$ we considered using induction VAV terminal [28] which enhanced jet flow velocity without additional fan. Maximal induction ratio 1 was assumed. This results in doubled inlet air flow rate. Enhanced nighttime natural ventilation with $A C H$ $=2 \mathrm{~h}^{-1}$ was assumed when indoor air temperature excided $22{ }^{\circ} \mathrm{C}$ and outdoor air temperature was $3 \mathrm{~K}$ lower of indoor air temperature.

Table 1. Various scenarios predicted in office thermal response calculations

\begin{tabular}{lcccccc}
\hline Scenario: & $\mathrm{A}_{3}$ & $\mathrm{~A}_{6}$ & $\mathrm{~B}_{3}$ & $\mathrm{~B}_{6}$ & $\mathrm{C}_{3}$ & $\mathrm{D}_{3}$ \\
\hline Length of TACW, $L_{\text {TACW }}[\mathrm{m}]$ & 3 & 6 & 3 & 6 & 3 & 3 \\
\hline Natural convection & + & + & & & & \\
\hline Jet flow enhanced convection & & & + & + & + & + \\
\hline $\begin{array}{l}\text { Outdoor airflow rate in occup. } \\
\text { hours, } q_{\mathrm{v}, \mathrm{e}}\left[\mathrm{m}^{3} / \mathrm{h}\right]\end{array}$ & 216 & 216 & 216 & 216 & 216 & 216 \\
\hline $\begin{array}{l}\text { Supply airflow rate in occupied } \\
\text { hours, } q_{\mathrm{v}, \mathrm{SA}}\left[\mathrm{m}^{3} / \mathrm{h}\right]\end{array}$ & 216 & 216 & 216 & 432 & 324 & 432 \\
\hline Supply air velocity, $v_{\mathrm{SA}}[\mathrm{m} / \mathrm{s}]$ & 0 & 0 & 2 & 2 & 3 & 4 \\
\hline
\end{tabular}

\section{RESULTS AND DISCUSSION}

Cooling efficiency was analyzed at the base of cooling degree hour $(C D H)$ as product of 'time when indoor operative temperature exceeds reference temperature' and 'temperature difference between exceeded indoor operative temperature and reference temperature' [29]:

$$
\sum_{j=1}^{N}\left(\vartheta_{i, j}-\vartheta_{\text {ref }}\right)^{+}
$$

where $j$ is the hour-to-hour calculated operative temperature as the arithmetical mean of the indoor air temperature and surface temperature, $\vartheta_{\text {ref }}$ is reference temperature and $N$ is the number of hours during the summer period. Sign "+" indicates that only positive values are taken into account in summation. As reference operative temperature, the adaptive indoor temperature was used regarding outdoor temperature, "alpha" building parameters set by Linden et al. [30] and Class A thermal comfort (90\% acceptance):

$$
\begin{aligned}
& \vartheta_{e}>12{ }^{\circ} \mathrm{C}: \vartheta_{\text {ref }}=20.3^{\circ} \mathrm{C}+0.31 \cdot \vartheta_{e}, \\
& \vartheta_{e}<12{ }^{\circ} \mathrm{C}: \vartheta_{\text {ref }}=22.7^{\circ} \mathrm{C}+0.11 \cdot \vartheta_{e} .
\end{aligned}
$$

Results are presented in Figs. 9 and 10 for two different internal heat gains values - for mid and high level. The analyzes shows that in case of office without TACW (scenario 1 and scenario 2), required thermal indoor comfort, indicated by $C D H$ equal or less to zero cannot be ensured even in case of low internal gains $\left(q_{\mathrm{IGH}}^{\prime \prime}=30 \mathrm{~W} / \mathrm{m}^{2}\right)$. At $L_{\mathrm{TACW}}=3 \mathrm{~m}$ mechanical cooling could be avoided only with enhanced convection in the case of medium internal gains. Enhanced convection with higher air jet velocities reduces overheating to $C D H=5 \mathrm{~K} \mathrm{~h}$ /year for scenario $\mathrm{C}_{3}\left(v_{\mathrm{SA}}=3 \mathrm{~m} / \mathrm{s}\right)$ and to only $C D H=0.3 \mathrm{~K} \mathrm{~h} /$ year for scenario $\mathrm{D}_{3}\left(v_{\mathrm{SA}}=4 \mathrm{~m} / \mathrm{s}\right)$. At medium level of internal gains natural convection even at $L_{\mathrm{TACW}}=6 \mathrm{~m}$ (scenario $\mathrm{A}_{6}$ ) cannot ensure suitable thermal comfort comparing enhanced convection which at the same length of TACW (scenario $\mathrm{B}_{6}$ ) satisfies adaptive thermal comfort criteria Class A. Enhancing heat transfer with higher air jet velocities at $L_{\mathrm{TACW}}=3 \mathrm{~m}$ does not bring satisfactory lower indoor operative temperatures at high level of internal heat gains. $C D H=114 \mathrm{~K} \mathrm{~h} /$ year is still too high for acceptable thermal indoor comfort in scenario $\mathrm{D}_{3}$ despite air jet velocity $v_{\mathrm{SA}}=4 \mathrm{~m} / \mathrm{s}$ (Fig. 10). However, on the another hand the same amount of supply air is used in scenario $\mathrm{B}_{6}\left(L_{\mathrm{TACW}}=6 \mathrm{~m}, v_{\mathrm{SA}}=2 \mathrm{~m} / \mathrm{s}\right)$, which is suitable to meet the thermal indoor comfort criteria in Class A at $q_{\mathrm{IGH}}^{\prime \prime}=60 \mathrm{~W} / \mathrm{m}^{2}$.

\section{CONCLUSIONS}

Cooling with thermo active building systems with natural convection enable noiseless operation, however cooling potential strongly depends on temperature differences between surface and adjacent air temperature. Cooling with natural convection is not easy to control and adapt to the current loads. Lowering of the TACW temperature could lead to thermal discomfort and surface condensation. Such cases can be significantly improved if convection is enhanced by supply air wall jet. This allows controlling heat transfer on TACW with slot velocity 
and also with a difference between supply air temperature and surface temperature.

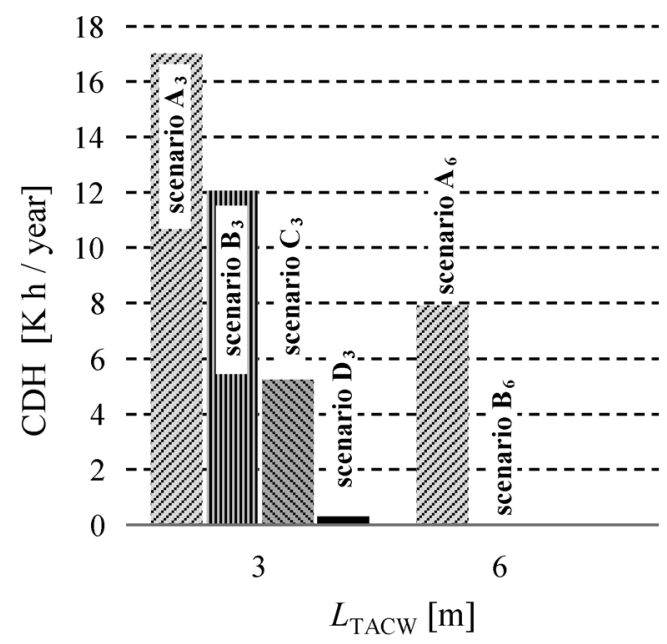

Fig. 9. $\mathrm{CDH}$ for the office with internal heat gains of $45 \mathrm{~W} / \mathrm{m}^{2}$

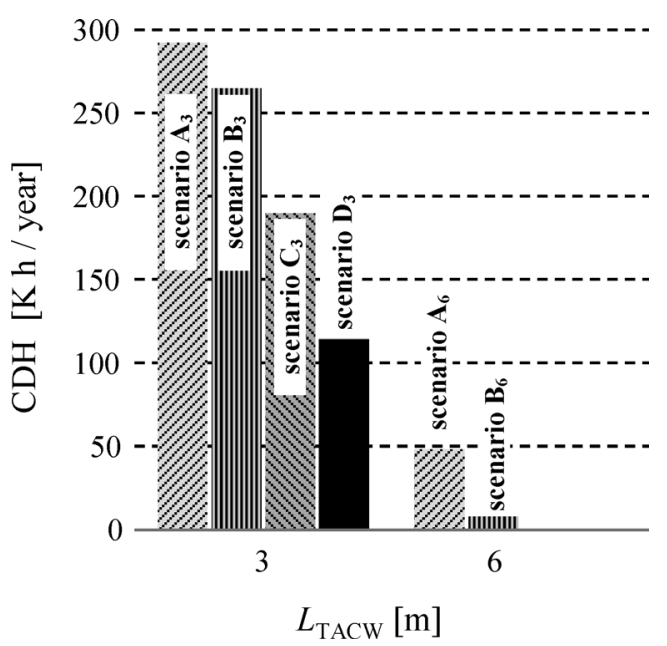

Fig. 10. $\mathrm{CDH}$ for the office with internal heat gains of $60 \mathrm{~W} / \mathrm{m}^{2}$

It was shown that in the case of enhanced convection with initial slot velocity $\left(v_{\mathrm{SA}}=2 \mathrm{~m} / \mathrm{s}\right)$ light level of internal heat gains can be easily covered with only $3 \mathrm{~m}$ of TACW. Additionally, at mid-level of internal heat gains enhanced mixed convection with slot velocity $\left(v_{\mathrm{SA}}=4 \mathrm{~m} / \mathrm{s}\right)$ practically meets Class A requirements for adaptive comfort criteria with a little, almost unrecognizable overheating: $C D H=0.3$ $\mathrm{K}$ h/year at only $L_{\text {TACW }}=3 \mathrm{~m}$. Natural convection is not able to cover those internal gains even at $L_{\mathrm{TACW}}$ $=6 \mathrm{~m}$. Here, the benefit of mixed convection can be seen. High level of internal gains $\left(60 \mathrm{~W} / \mathrm{m}^{2}\right)$ can be covered only with mixed convection at $L_{\mathrm{TACW}}=6 \mathrm{~m}$ at acceptable: $C D H=8 \mathrm{~K} \mathrm{~h}$ /year. From the results it can be concluded that the size of TACW surface can be significantly reduced if convective heat transfer is enhance by the supply air wall jet.

\section{NOMENCLATURE}

List of symbols

\begin{tabular}{|c|c|c|}
\hline$A C H$ & Air Changes per Hour & {$[1 / \mathrm{h}]$} \\
\hline$C D D$ & Cooling Degree Days & [K day/year $]$ \\
\hline $\mathrm{CDH}$ & Cooling Degree Hours & [K h/year] \\
\hline$\Delta$ & difference & \\
\hline$\in$ & heat recovery efficiency & {$[\%]$} \\
\hline$g$ & gravity & {$\left[\mathrm{m} / \mathrm{s}^{2}\right]$} \\
\hline$h$ & heat transfer coefficient & {$\left[\mathrm{W} /\left(\mathrm{m}^{2} \mathrm{~K}\right)\right]$} \\
\hline$L$ & length & {$[\mathrm{m}]$} \\
\hline$q_{\mathrm{v}}$ & volumetric airflow rate & {$\left[\mathrm{m}^{3} / \mathrm{h}\right]$} \\
\hline$q "$ & heat flux & {$\left[\mathrm{W} / \mathrm{m}^{2}\right]$} \\
\hline$R^{2}$ & Pearson correlation coefficient & {$[/]$} \\
\hline$\vartheta$ & temperature in Celsius & {$\left[{ }^{\circ} \mathrm{C}\right]$} \\
\hline$\sigma$ & standard deviation & {$\left[\mathrm{W} /\left(\mathrm{m}^{2} \mathrm{~K}\right)\right]$} \\
\hline$U$ & overall heat transfer coefficient & {$\left[\mathrm{W} /\left(\mathrm{m}^{2} \mathrm{~K}\right)\right]$} \\
\hline$v$ & velocity & {$[\mathrm{m} / \mathrm{s}]$} \\
\hline$x$ & stream wise coordinate & {$[\mathrm{m}]$} \\
\hline$y$ & transverse coordinate & {$[\mathrm{m}]$} \\
\hline CFD & Computational Fluid Dynamic & \\
\hline HVAC & Heating Ventilating and Air & \\
\hline & Conditioning & \\
\hline PMV & Predicted Mean Value & \\
\hline PPD & Percentage of People Dissatisfied & \\
\hline TABS & Thermo Active Building Systems & \\
\hline TACW & Thermo Active Cooling Wall & \\
\hline TRY & Test Reference year & \\
\hline VAV & Variable Air Volume & \\
\hline \multicolumn{3}{|c|}{ Subscripts } \\
\hline avg & average & \\
\hline app & approximation & \\
\hline $\mathrm{c}$ & convection & \\
\hline e & outdoor & \\
\hline floor & floor & \\
\hline$i$ & indoor & \\
\hline IHG & Internal Heat Gains & \\
\hline$j$ & hour-to-hour calculated operative & mperature \\
\hline$N$ & number of TRY hours & \\
\hline num & Value based on numerical simulati & \\
\hline ref & reference value & \\
\hline SA & Supply Air & \\
\hline $\mathrm{w}$ & wall & \\
\hline win & window & \\
\hline 3 & length of TACW: $3 \mathrm{~m}$ & \\
\hline 6 & length of TACW: $6 \mathrm{~m}$ & \\
\hline
\end{tabular}




\section{ACKNOWLEDGEMENT}

This study was partially financed by the European Union, European Social Fund.

\section{REFERENCES}

[1] Vidrih. B., Medved. S. (2008). The effect of changes in the climate on the energy demands of buildings. International Journal of Energy Research, vol. 32, no. 11, p. 1016-1029, DOI:10.1002/er.1410.

[2] Vidrih, B., Dolinar, M., Medved, S. (2006). The connection between the climate model and a building's thermal response model: a case of Slovenia. Strojniški vestnik - Journal of Mechanical Engineering, vol. 52, no. 9, p. 568-586.

[3] Kalz, D., Pfafferott, J., Herkel, S. (2006). Monitoring and data analysis of two low energy office buildings with a thermo-active building system (TABS). AIVC27th conference - EPIC 2006 AIVC "Technologies \& sustainable policies for a radical decrease of the energy consumption in buildings", p. 217-222.

[4] Lehmann, B., Dorer, V., Koschenz, M. (2007). Application range of thermally activated building systems TABS. Energy and Buildings, vol. 39, no. 5, p. 593-598, DOI:10.1016/j.enbuild.2006.09.009.

[5] Koschenz, M., Dorer, V. (1999). Interaction of an air system with concrete core conditioning. Energy and Buildings, vol. 30, no. 2, p. 139-145, DOI:10.1016/ S0378-7788(98)00081-4.

[6] Košir, M., Krainer, A., Dovjak, M., Perdan, R., Kristl, Ž. (2010). Alternative to the Conventional Heating and Cooling Systems in Public Buildings. Strojniški vestnik - Journal of Mechanical Engineering, vol. 56, no. 9, p. 575-583.

[7] Henze, G.P., Felsmann, C., Kalz, D.E., Herkel, S. (2008). Primary energy and comfort performance of ventilation assisted thermo-active building systems in continental climates. Energy and Buildings, vol. 40, no. 2, p. 99-111, DOI:10.1016/j.enbuild.2007.01.014.

[8] Dovjak, M., Shukuya, M., Krainer, A. (2012). Exergy analysis of conventional and low exergy systems for heating and cooling of near zero energy buildings. Strojniški vestnik - Journal of Mechanical Engineering, vol. 58, no. 7-8, p. 453-461, DOI:10.5545/svjme.2011.158.

[9] Kobus, C.J., Wedekind, G.L. (1996). Modeling the local and average heat transfer coefficient an isothermal vertical flat plate with assisting and opposing combined forced and natural convection. International Journal of Heat and Mass Transfer, vol. 39, no. 13, p. 2723-2733, DOI:10.1016/0017-9310(95)00360-6.

[10] Yang, J. W., Patel, R. D. (1973). Effect of buoyancy on forced convection in a two -dimensional wall jet along a vertical wall. Journal of Heat Transfer, vol. 95, no. 1, p. 121-123, DOI:10.1115/1.3449980.

[11] Angirasa, D. (2000). Mixed convection in a vented enclosure with isothermal vertical surface. Fluid
Dynamics Research, vol. 26, no. 4, p. 219-233, DOI:10.1016/S0169-5983(99)00024-6.

[12] Mokni, A., Kechiche, J., Mhiri, H., Le Palec, G., Bournot, P. (2009). Inlet conditions effects on vertical wall jets in forced and mixed convection regimes. International Journal of Thermal Science, vol. 48, no. 10, p. 1884-1893, DOI:10.1016/j. ijthermalsci.2009.02.021.

[13] Neiswanger, L., Johnson, G.A., Carey, V.P. (1987). An experimental study of high Rayleigh number mixed convection in a rectangular enclosure with restricted inlet and outlet openings. Journal of Heat Transfer, vol. 109, no. 2, p. 446-453, DOI:10.1115/1.3248102.

[14] Awbi, H.B., Hatton, A. (2000). Mixed convection from heated room surfaces. Energy and Buildings, vol. 32, no. 2, p. 153-166, DOI:10.1016/S0098-8472(99)000635.

[15] Awbi, H.B., Hatton, A. (1999). Natural convection from heated room surfaces. Energy and Buildings, vol. 30, p. 233-244, DOI:10.1016/S0378-7788(99)00004-3.

[16] Goldstein, K., Novoselac, A. (2010). Convective heat transfer in rooms with ceiling slot diffusers. $H V A C \& R$ Research, vol. 16, no. 5, p. 629-656, DOI:10.1080/1078 9669.2010.10390925.

[17] Ternik, P., Rudolf, R. (2012). Heat transfer enhancement for natural convection flow of waterbased nanofluids in a square enclosure. International Journal of Simulation Modelling, vol. 11, no. 1, p. 2939, DOI:10.2507/IJSIMM11(1)3.198.

[18] 2001 ASHRAE Handbook Fundamentals. (2001). ASHRAE, Atlanta.

[19] Khalifa, A.J.N., Marshall, R.H. (1989). Natural and forced convection on interior building surfaces: preliminary results. Applied Research Conference, p. 249-257.

[20] Spitler, J.D., Pedersen, C.O., Fisher, D.E., Menne, P.F., Cantillo, J. (1991). An experimental facility for investigation of indoor convective heat transfer. ASHRAE Transactions 97, vol. 1, p. 497-504.

[21] Spitler, J.D., Pedersen, C.O., Fisher, D.E., Menne, P.F., Cantillo, J. (1991). Interior convective heat transfer in buildings with large ventilative flow rates. ASHRAE Transactions 97, vol. 1, p. 505-515.

[22] TRNSYS, from http://www.trnsys.com, accessed on 2012-03-08.

[23] Ministry of Agriculture and Environment - Slovenian Environment Agency, from http://meteo.arso.gov.si/ met/sl/climate/tables/test_ref_year, accessed on 201203-08.

[24] CR 1752:1998 (1998). Ventilation for buildings Design criteria for the indoor environment, European Standard. CEN, Brussels.

[25] Rules on the ventilation and air-conditioning of buildings (2002). Official Gazzete of the Republic of Slovenia, vol. 42, p. 4139-4161. (in Slovene)

[26] Božović, M. (2004). Report of pumping test at well $F K-1$ in Zagorje. Preliv d.o.o., Ljubljana. (in Slovene) 
[27] Corgnati, S.P., Kindinis, A. (2007). Thermal mass activation by hollow core slab coupled with night ventilation to reduce summer cooling loads. Building and Environment, vol. 42, no. 9, p. 3285-3297, DOI:10.1016/j.buildenv.2006.08.018.

[28] HC Barcol-Air, from http://www.barcol-air.nl/PDF\%20 documentatie/VAV\%20CAV\%20documentation $\% 20 \mathrm{NV}$. $p d f$, accessed on 2012-03-08.

[29] Papakostas, K., Kyriakis, N. (2005). Heating and cooling degree-hours for Athens and Thessaloniki,
Greece. Renewable Energy, vol. 30, no. 12, p. 1873 1880, DOI:10.1016/j.renene.2004.12.002.

[30] Van der Linden, A.C., Boerstra, A.C., Raue, A.K., Kurvers, S.R., de Dear, R.J. (2006). Adaptive temperature limits: A new guideline in The Netherlands: A new approach for the assessment of building performance with respect to thermal indoor climate. Energy and Buildings, vol. 38, no. 1, p. 8-17, DOI:10.1016/j.enbuild.2005.02.008. 